\title{
Determination of Antifungal Activity Against Invasive Candidiasis Agents and Trace Element Content of Fig Tree Latex Samples Obtained from Trabzon Province
}

\author{
Trabzon Bölgesinden İzole Edilen İncir A ğacı Latekslerinin İnvazif Kandidiyazis \\ Etkenlerine Karşı Antifungal Aktivitesinin ve Eser Element Düzeylerinin İncelenmes
}

\author{
Özge ÜNLÜ1), Fatma ATES ALKAN ${ }^{2 *}$, Nural PASTACI ÖZSOBACI ${ }^{3}$, \\ Sedanur ÖZYÜKSEL ${ }^{4}$ (D) , Mehmet DEMİRCi ${ }^{5}$ \\ ${ }^{1}$ Beykent University Faculty of Medicine, Department of Medical Microbiology, 34500, Istanbul, Turkey \\ ${ }^{2 *}$ Beykent University Faculty of Medicine, Department of Biophysics, 34500, Istanbul, Turkey \\ ${ }^{3}$ Istanbul University-Cerrahpasa, Faculty of Medicine Cerrahpasa, Department of Biophysics, 34098, Istanbul, \\ Turkey \\ ${ }^{4}$ Beykent University Faculty of Medicine, ${ }^{\text {th }}$ Grade Student, 34500, Istanbul, Turkey \\ ${ }^{5}$ Kırklareli University Faculty of Medicine, Department of Medical Microbiology, 39100, Kırklareli, Turkey
}

\begin{abstract}
Candidiasis is a major health concern causing both morbidity and mortality. The increasing prevalence of antimicrobialresistant fungi associated with life-threatening systemic mycoses, led a constant need for new antifungal agents. Herbal medicines have been tried for this purpose for centuries. The antifungal effect of fig tree latex has been reported and some trace elements such as zinc were associated with antifungal effects. The aim of this study was to determine the trace element content and in-vitro antifungal activity of fig tree latex sample against Candida. albicans, C. glabrata, C. tropicalis and C. krusei. Fig tree latex samples were obtained from four different fig tree at Trabzon province in July 2019. The broth microdilution technique was performed to investigate antifungal activity against standard Candida strains and trace elements level were detected with Inductively Coupled Plasma Optical Emission Spectrophotometer (ICP-OES) analyzer. The most powerful antifungal activity was reached at a concentration of 0.5 for $C$. albicans and $C$. tropicalis, and at a concentration of 0.125 for C. krusei and C. glabrata in fig tree latex. According to trace element analysis, magnesium had the highest level, followed by calcium and phosphorus. Selenium, aluminium, lead and nickel levels were too low to be measured. As a conclusion, fig tree latex has an antifungal potential against Candida species and this may be caused by the high level of magnesium that it contains, however more studies are needed to understand the therapeutic effects of fig tree latex.
\end{abstract}

Keywords: fig tree latex, Ficus carica, Candida, antifungal activity, trace elements

\section{$\ddot{O} \mathbf{z}$}

Kandidiyazis, morbidite ve mortaliteye neden olan önemli bir halk sağlığı sorunudur. Hayatı tehdit eden sistemik mikozlara neden olan antimikrobiyal dirençli mantarların sayısındaki artış, yeni antifungal ajanlara olan ihtiyacı doğurmuştur. Bitkisel ilaçlar bu amaçla yüzyıllardır kullanılmaktadır. İncir ağacı lateksinin antifungal etkisi önceki çalışmalarda rapor edilmiş, buna ek olarak çinko gibi bazı eser elementlerin de antifungal etkileri çeşitli çalışmalarla ortaya konmuştur. Çalışmamızda, incir ağacı lateksinin Candida. albicans, $C$. glabrata, C. tropicalis ve $C$. krusei'ye karşı in vitro antifungal aktivitesinin belirlenmesi ve içeriğindeki eser elementlerin ortaya konarak, bu eser elementlerin potansiyel antifungal etkilerinin incelenmesi amaçlandı. İncir ağacı lateks numuneleri, Temmuz 2019'da Trabzon ilindeki dört farklı incir ağacindan elde edilmiştir. Latekslerin standart Candida kökenlerine karşı antifungal etkisini araştırmak için mikrodilüsyon tekniği uygulandı ve İndüktif Eşleşmiş Plazma Optik Emisyon Spektrofotometresi (ICP-OES) kullanılarak eser element seviyesi tespit edildi. İncir ağacı latekslerinde $C$. albicans ve $C$. tropicalis için 0.5 konsantrasyonda, $C$. krusei ve $C$.glabrata için ise 0.125 konsantrasyonda en güçlü antifungal aktiviteye ulaştığı saptandı. Eser element analizine göre incir ağacı lateksinde en yüksek konsantrasyonda bulunan elementler sırasıyla magnzeyum, kalsiyum ve fosfor olarak saptandı. Selenyum, aluminyum, kurşun ve nikel seviyeleri ise ölçülemeyecek kadar düşük olarak kaydedildi. Çalışmamıza göre incir ağacı lateksinin Candida türlerine karşı antifungal potansiyeli olduğu görülmüş ve aktivitenin lateksin içerdiği yüksek magnezyum seviyesinden kaynaklanıyor olabileceği düşünülmüştür. Ancak incir ağacı lateksinin terapötik etkilerinin ortaya konulması için daha fazla çalışmaya ihtiyaç vardır.

Anahtar kelimeler: incir ağacı lateksi, Ficus carica, Candida, antifungal etki, eser elementler 


\section{INTRODUCTION}

Candidiasis is a major health concern increasing both morbidity and mortality. It is known that there are at least 15 different Candida species that cause infections in humans. However, the four most common species detected in more than $90 \%$ of invasive diseases related to Candida species are Candida albicans, C. glabrata, C. tropicalis and C. krusei. Each of these organisms has unique virulence potential, antifungal sensitivity, and epidemiology [1]. As a result of the increasing prevalence of antimicrobial-resistant fungi associated with life-threatening systemic mycoses, there is a constant need for new antifungal agents. Because fungi have eukaryotic cell structure, their similarity with host cells creates additional problems in the design of drugs with selective toxicity to fungal cells in the treatment of these infections [2]. Herbal medicines have played an important role in the protection of individuals' health for thousands of years all over the world [3]. When the frequency of the usage of complementary and alternative drugs in general populations is examined, it has been understood that herbal drugs are quite popular in recent years [4]. The fig tree is one of the oldest trees belonging to the Moraceae family. Its product, Ficus carica L., is one of the earliest cultivated crops in the world due to its nutritional and medicinal benefits. The fruit can be consumed both in dry and fresh form. Mediterranean countries such as Turkey are the leading manufacturers of this product due to suitable climate [5]. In addition, fig tree latex ("ficin", a common milky secretion of fig tree leaves and fruits) has different therapeutic effects [6]. The antifungal effect of fig tree latex has been reported in previous studies, however, the cause of this antifungal effect was not examined in these studies $[7,8]$.

Trace elements are essential inorganic elements for life and are cofactors or catalysts in enzyme activity. When taken insufficiently, it causes dysfunction by affecting biological functions and only physiological doses are needed for the continuation of normal tissue functions. Trace elements such as iron $(\mathrm{Fe})$, copper $(\mathrm{Cu})$, zinc $(\mathrm{Zn})$, selenium $(\mathrm{Se})$, etc. play crucial roles in many biological systems [9, 10]. For instance, in C. albicans, these ions can participate in the provision of membrane potential, regulation of cell volume, cell proliferation and apoptosis mechanisms [10]. In addition to this, some trace elements such as $\mathrm{Zn}$ and Se compounds were associated with antifungal agents $[11,12]$. When the trace elements found in figs were examined, the presence of different trace elements was reported [13].

In our study, it was aimed to reveal the in-vitro antifungal activity of fig tree latex against $C$. albicans, C. glabrata, C. tropicalis and C. krusei which are the species responsible for over $90 \%$ of invasive candidiasis, also to determine the levels of the trace elements in the fig tree latex and to evaluate the trace elements that may contribute to the antifungal activity.

\section{MATERIALS AND METHODS}

\subsection{Antifungal Activity Assays}

In this study, the broth microdilution technique was utilized to investigate the effect of fig tree latex on the growth of Candida species according to Clinical Laboratory Standards Institute (CLSI) criteria. In order to achieve this objective, C. albicans American Type Culture Collection (ATCC) 10231, C. tropicalis ATCC 750, C. krusei ATCC 6258 ve C. glabrata ATCC 2001 strains were used. Fig tree latex samples were obtained from four different fig tree from Trabzon region (Turkey) in July 2019 and latexes were transferred to the laboratory under sterile conditions in microcentrifuge tubes. Each fig tree latex was individually tested against four different Candida species. $10 \mu \mathrm{L}$ fig tree latex sample was added directly to the first well of the 96 well plate which contains 80 $\mu \mathrm{L}$ Brain Heart Infusion (BHI) broth in each well. Then, latex diluted $0.5,0.25,0.125$ ve 0.0625 (dilution coefficient) fold with BHI broth. Also, the same volume of BHI was used as the negative control. Broth cultures of Candida species were adjusted to 0.5 McFarland turbidity standard individually and were inoculated into each well. The absorbances of the time T0 were measured spectrophotometrically at optical density at $600 \mathrm{~nm}$ (OD 600) in the Epoch System (Biotek Instruments, USA) according to the manufacturer's instructions. After incubation at $37^{\circ} \mathrm{C}$ for 24 hours, the absorbance values of T24 time were measured and values were compared with T0 absorbances in order to evaluate fungal growth. All experiments were performed in triplicate [14].

\subsection{Trace Element Analysis}

Fig tree latex samples were prepared for element measurements by diluting 1:10 with deionized water. The analysis of chromium $(\mathrm{Cr}), \mathrm{Cu}, \mathrm{Fe}$, magnesium $(\mathrm{Mg})$, manganese $(\mathrm{Mn}), \mathrm{Se}, \mathrm{Zn}$, aluminium (Al), calcium (Ca), phosphorus (P), cobalt (Co), cadmium $(\mathrm{Cd})$, lead $(\mathrm{Pb})$, arsenic (As), boron (B), nickel (Ni) and silicium ( $\mathrm{Si}$ ) levels were performed with ICP-OES Thermo iCAP 6000 series at Trace Element Analysis Laboratory of Biophysics Department of Cerrahpasa Medical Faculty at Istanbul University-Cerrahpasa.

The favorable wavelengths, 267.716, 324.754, 259.940, 285.213, 257.610, 196.090, 206.200, 167.090, 317.933, 177.495, 228.616, 249.773, 189.042, 249.773, 221.647 and $251.611 \mathrm{~nm}$, were used for the determinations of $\mathrm{Cr}, \mathrm{Cu}, \mathrm{Fe}, \mathrm{Mg}, \mathrm{Mn}, \mathrm{Se}, \mathrm{Zn}, \mathrm{Al}, \mathrm{Ca}$, $\mathrm{P}, \mathrm{Co}, \mathrm{Cd}, \mathrm{Pb}, \mathrm{As}, \mathrm{B}, \mathrm{Ni}$ and $\mathrm{Si}$ levels, respectively, in the ICP-OES device.

\subsection{Reagents}

ICP-OES labor standards were prepared from appropriate standard solutions including $1.000 \mathrm{ppm}$ for each tested element obtained from Chem Lab NV located in Zedelgem/Belgium. Reagents with analytical reagent grade and deionized water were used. Stock solutions of $\mathrm{Cr}, \mathrm{Cu}, \mathrm{Fe}, \mathrm{Mg}, \mathrm{Mn}, \mathrm{Se}, \mathrm{Zn}, \mathrm{Al}, \mathrm{Ca}, \mathrm{P}, \mathrm{Co}$, 
$\mathrm{Cd}, \mathrm{Pb}, \mathrm{As}, \mathrm{B}, \mathrm{Ni}$ and $\mathrm{Si}$ were prepared by taking the appropriate standard in deionized water. Solutions were prepared freshly before using doubly deionized water was used in this study. To reduce the risk of contamination from ambient air and dust, all process was performed on a clean bench. All the volumetric flasks used were cleaned soaking in with $10 \%(\mathrm{v} / \mathrm{v})$ nitric acid $\left(\mathrm{HNO}_{3}\right)$ solution during the day before use. These were rinsed with deionized water thoroughly and dried in an oven overnight at $100{ }^{\circ} \mathrm{C}$ [15]. F. carica L. levels of analyzed elements were expressed in micrograms per milliliter $(\mu \mathrm{g} / \mathrm{mL})$ [16]. Measurement of each trace element level was carried out three times and averaged.

\section{RESULTS AND DISCUSSION}

Antifungal activity assays revealed the most powerful antifungal activity was reached at a concentration of 0.5 for $C$. albicans and C. tropicalis, and at a concentration of 0.125 for $C$. krusei and C. glabrata in fig tree latex taken at different times. The fungal growth suppression rates of Candida strains according to the fig tree latex dilution rates are given in Table 1 and Figure 1, and the relative growth rates of Candida strains as colonyforming unit (CFU) are given in Table 2.

Minerals, trace and toxic element levels of $F$. carica $\mathrm{L}$ samples were given in Table 3. According to trace element analysis, $\mathrm{Mg}$ has the highest level, followed by $\mathrm{Ca}$ and $\mathrm{P}$. Se, $\mathrm{Al}, \mathrm{Pb}$ and $\mathrm{Ni}$ levels were too low to be measured. All element levels are given in Table 3.

Table 1. Growth suppression rates of Candida strains according to the concentrations of fig tree latexes $(\%)$

\begin{tabular}{llllll}
\hline & $\mathbf{1}$ & $\mathbf{0 . 5}$ & $\mathbf{0 . 2 5}$ & $\mathbf{0 . 1 2 5}$ & $\mathbf{0 . 0 6 2 5}$ \\
\hline C. albicans & $55.19 \%$ & $90.74 \%$ & $86.44 \%$ & $87.04 \%$ & $69.99 \%$ \\
C. tropicalis & $67.36 \%$ & $68.06 \%$ & $63.92 \%$ & $65.98 \%$ & $51.23 \%$ \\
C. krusei & $75.20 \%$ & $75.35 \%$ & $72.03 \%$ & $79.73 \%$ & $63.25 \%$ \\
\hline C. glabrata & $64.59 \%$ & $51.99 \%$ & $84.98 \%$ & $87.47 \%$ & $73.36 \%$ \\
\hline
\end{tabular}

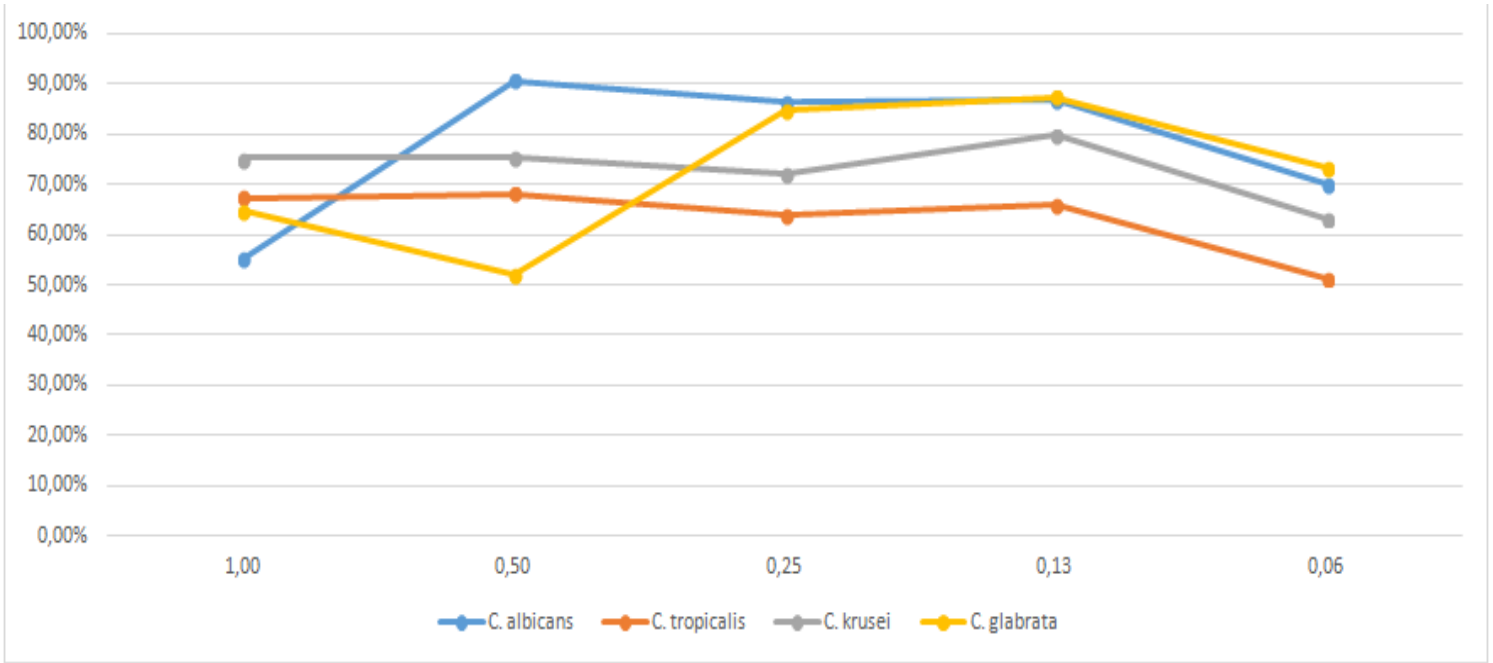

Figure 1. Growth suppression rates of Candida species by fig tree latex (\%)

Table 2. Relative growth rates of Candida strains as CFU in medium supplemented with different concentrations of fig tree latex samples (Means + SD.) $\left(\mathrm{CFU} / \mathrm{mL}^{*} 10^{5}\right)$

\begin{tabular}{llllll}
\hline & $\mathbf{1}$ & $\mathbf{0 . 5}$ & $\mathbf{0 . 2 5}$ & $\mathbf{0 . 1 2 5}$ & $\mathbf{0 . 0 6 2 5}$ \\
\hline C. albicans & $8.96 \underline{ \pm 6.49}$ & $1.85 \pm 2.22$ & $2.71 \pm 4.14$ & $2.59 \pm 2.97$ & $6.00 \pm 3.45$ \\
C. tropicalis & $6.53 \pm 3.95$ & $6.39 \pm 3.12$ & $7.22 \pm 7.28$ & $6.80 \pm 4.40$ & $9.75 \pm 6.34$ \\
C. krusei & $4.96 \pm 3.92$ & $4.93 \pm 4.47$ & $5.59 \pm 6.18$ & $4.05 \pm 5.20$ & $7.35 \pm 6.22$ \\
C. glabrata & $7.08 \pm 7.64$ & $9.60 \pm 6.92$ & $3.00 \pm 5.20$ & $2.51 \pm 2.72$ & $5.33 \pm 4.99$ \\
\hline
\end{tabular}

CFU: Colony-forming unit 
Table 3. Trace element levels of $F$. carica L. samples

\begin{tabular}{lcc}
\hline Element & $\begin{array}{c}\text { Results } \\
(\boldsymbol{\mu g} / \mathbf{m L})\end{array}$ & SD \\
\hline $\mathrm{Cr}$ & 0.06 & 0.03 \\
$\mathrm{Cu}$ & 0.27 & 0.13 \\
$\mathrm{Fe}$ & 0.37 & 0.21 \\
$\mathrm{Mg}$ & 2688.93 & 610.30 \\
$\mathrm{Mn}$ & 0.16 & 0.07 \\
$\mathrm{Se}$ & $\mathbf{N D}$ & $\mathbf{N D}$ \\
$\mathrm{Zn}$ & 0.35 & 0.22 \\
$\mathrm{Al}$ & $\mathbf{N D}$ & $\mathbf{N D}$ \\
$\mathrm{Ca}$ & 70.98 & 10.49 \\
$\mathrm{P}$ & 29.42 & 9.18 \\
$\mathrm{Co}$ & 0.04 & 0.03 \\
$\mathrm{Cd}$ & 0.03 & 0.01 \\
$\mathrm{~Pb}$ & $\mathbf{N D}$ & $\mathbf{N D}$ \\
$\mathrm{As}$ & 0.51 & 0.21 \\
$\mathrm{~B}$ & 0.68 & 0.43 \\
$\mathrm{Ni}$ & $\mathbf{N D}$ & $\mathbf{N D}$ \\
$\mathrm{Si}$ & 0.96 & 0.25 \\
\hline $\mathrm{Cr}$, chromium; $\mathrm{Cu}$, copper; Fe, iron; Mg, magnesium; Mn; manganese; Se, selenium; Zn, zinc; Al, aluminium;
\end{tabular}

$\mathrm{Ca}$, calcium; P, phosphorus; Co, cobalt; Cd, cadmium; Pb, lead; As, arsenic; B, boron; Ni, nickel; Si, silicium. ND: non-detectable. Data are shown as the Means \pm SD.

Candida species are the most important pathogens of opportunistic mycoses. In addition to superficial and mucosal infections such as oral candidiasis and vulvovaginal candidiasis, which are common in healthy hosts, they also have the potential to cause systemic infection in the immunosuppressive host. Although more than fifteen Candida species that can infect humans have been identified, it is known that $C$. albicans, C. glabrata, C. tropicalis and C. krusei are responsible for $90 \%$ of human infections [1]. Antifungal resistance emerging in Candida is an important public health problem that causes failure in the treatment of candidiasis. The development of new antifungals against increased antifungal resistance and the discovery of substances with antifungal activity are crucial [2]. Herbal treatment methods have been used in the treatment of superficial infections for many years, and especially in recent years, interest in these traditional treatment approaches has increased [3, 4]. One of the plants that have been used for many years for this purpose is fig, in which Turkey is among the leading producers. Fig (Ficus carica L.) is a nutritious plant belonging to the Moraceae family, whose therapeutic effects have been revealed in many studies [5-8]. One of the most important therapeutic effects of $F$. carica L. is the wound healing effect, which is claimed to be caused by the latex of the fig tree. Fig tree latex is a milky substance that is highly secreted from many parts of the fig tree such as young shoots, pedicles and leaves. Fig tree latex, which is secreted especially from the injured area of the fig tree, covers the area and protects it against to invasion of pathogens [8].
Probably with the observation of this effect, fig tree latex has begun to be used in traditional treatment of human wounds. In addition to its wound healing effect, there are many studies investigating the antifungal effect of fig tree latex [7, 8]. Despite its proven antifungal effect, there are no studies examining which active ingredient of the fig tree latex causing this antifungal effect. Therefore, in our study, it was aimed to investigate the antifungal effect of fig tree latex on Candida species, and to reveal the trace elements in the fig tree latex collected from our country and to examine the potential antifungal effects of these trace elements.

Aref et al. examined the antifungal effects of the extracts prepared from fig tree latex in their studies and they demonstrated that different extracts exerted different antifungal effects on different fungal species such as C. albicans, Aspergillus fumigatus, Microsporum canis, Cryptococcus neoformans Trichophyton rubrum, T. soudanense and Scopulariopsis brevicans. The most resistant species were determined as T. rubrum, $T$. soudanense and $S$. brevicans, and it was observed that fig tree latex inhibit the related species at rates varying between $0 \%$ and $60 \%$ [7].

Raskovic et al. investigated the antifungal effect of fig tree latex collected between May and August from Bar Region of Montenegro on Saccaromyces cerevisiae. According to the results of their study, that fig milk collected between May and June had a higher antifungal effect than the latex collected between July 
and August due to the high chitinolytic activity in the fig tree in the relevant months [8].

In the study conducted by Ahmed in 2016, the antimicrobial effect of latexes obtained from Ficus carica and Ficus elastica species was examined on many bacteria and fungal species, and it was reported that the antifungal activity of fig tree latex was high against all the yeast strains examined. It was stated that the fig latex obtained from $F$. carica was more effective compared to $F$. elastica latex and according to agar well diffusion results, inhibition zone diameters varied between $30 \mathrm{~mm}$ and $12 \mathrm{~mm}$ against different yeast species. The highest inhibition zone was observed against $C$. tropicalis $(30 \mathrm{~mm})$, followed by $C$. albicans (25 mm), C. sojae (22 mm), C. kefyr (19 mm) species, and the lowest antifungal effect was observed against C. krusei $(14 \mathrm{~mm})$ and C. neoformans $(12 \mathrm{~mm})$ species [17].

In our study, it was observed that fig tree latex in different concentrations suppressed the growth of different Candida species at different rates. It was observed that fig tree latex showed the highest antifungal activity against $C$. albicans and $C$. tropicalis at the concentration of 0.5 , and the concentration of 0.125 against $C$. krusei and $C$. glabrata. Growth of $C$. albicans was suppressed $91 \%$ at 0.5 concentration, while $C$. tropicalis growth was suppressed by $68 \%$. The growth of $C$. krusei was inhibited by $80 \%$ at the concentration of 0.125 and the growth of $C$. glabrata was suppressed by $87 \%$. It is noteworthy that fig tree latex suppresses the growth of different Candida species at different dilution rates. It is also striking that, contrary to expectations, higher antifungal activity was not obtained when fig tree latexes were applied to Candida species at maximum concentration without dilution.

Trace elements such as $\mathrm{Mg}, \mathrm{Ca}, \mathrm{Fe}, \mathrm{Cu}, \mathrm{Zn}, \mathrm{Se}$, etc. plays vital roles in biological systems such as, providing membrane potential, regulation of cell volume, cell proliferation or participation in apoptosis mechanisms [9-12]. In addition to this, the antimicrobial activities of some trace elements are known $[11,12]$. Although the antifungal effectiveness of fig tree latex has been known for years, there are no studies on active compounds that cause this activity. In our study, we aimed to examine the trace elements found in fig tree latex and reveal the elements that may cause or support this antifungal activity.

In our study, the minerals, trace and toxic element levels in fig tree latex were examined, and the elements with the highest concentrations were found as $\mathrm{Mg}, \mathrm{Ca}$ and $\mathrm{P}$, respectively. There are studies in the literature regarding the antifungal effectiveness of some trace elements, particularly magnesium oxide. Karimiyan et al. investigated the antifungal activity of magnesium oxide, zinc oxide, silicon oxide and copper oxide nanoparticles on $C$. albicans in their study and reported that the minimum inhibitory concentration (MIC) value of magnesium oxide nanoparticles against $C$. albicans was higher than $3200 \mu \mathrm{g} / \mathrm{mL}$. In our study, the magnesium ratio in fig tree latex was found to be 2989 $\mu \mathrm{g} / \mathrm{mL}$, suggesting that the magnesium concentration may have contributed to the antifungal effect of fig tree latex. In the same study, the MIC values of zinc oxide and copper oxide nanoparticles against $C$.albicans were found to be 200 and $400 \mu \mathrm{g} / \mathrm{mL}$, respectively, and their antifungal activities were evaluated as higher than magnesium oxide nanoparticles. However, in our study, because the zinc and copper ratios in fig tree latex were detected as very low, it cannot be said that the antifungal effect of fig tree latex we observed in our study was caused by the relevant elements [18].

Kong et al. investigated the antifungal effectiveness of magnesium oxide nanoparticles against $C$. albicans in 2020 and they found the MIC value as $391 \mu \mathrm{g} / \mathrm{mL}$. Besides, it has been demonstrated that magnesium oxide nanoparticles significantly inhibited the adhesion of $C$. albicans by adhesion experiments $(\mathrm{p}<0.001)$. As a result, they reported that magnesium oxide nanoparticles effectively inhibited the growth, adhesion, morphological transformation and biofilm formation of $C$. albicans and mentioned that magnesium oxide nanoparticles may be an effective antifungal candidate [19].

\section{CONCLUSION}

In our study, the most common elements found in fig tree latex after $\mathrm{Mg}$ were $\mathrm{Ca}$ and $\mathrm{P}$, respectively. However, there have been no studies investigating the antifungal efficacy of these two elements in the literature, so it is not possible to compare the antifungal efficacy of the related elements at this stage. More studies are needed in this field in order to evaluate the antifungal potential of other minerals, trace and toxic elements measured in fig tree latex.

In conclusion, fig tree latex has an antifungal potential on Candida species and this may be caused by the high level of magnesium that it contains however more studies are needed on the therapeutic use of fig tree latex. Also, according to the results of our in vitro study, before the usage of fig tree latex for antifungal purposes, it is necessary to know which fungal agent it will be used against and to use it at the appropriate concentration for that agent.

\section{REFERENCES}

[1] Pappas, P. G., Kauffman, C. A., Andes, D. R., Clancy, C. J., Marr, K. A., Ostrosky-Zeichner, L., Reboli, A. C., Schuster, M. G., Vazquez, J. A., Walsh, T. J., Zaoutis, T. E., \& Sobel, J. D. (2016). Clinical practice guideline for the management of Candidiasis: 2016 Update by the Infectious Diseases Society of America. Clin. Infec. Dis., 62(4), e1-e50. 
[2] Mazu, T. K., Bricker, B. A., Flores-Rozas, H., \& Ablordeppey, S. Y. (2016). The mechanistic targets of antifungal agents: An overview. Mini Reviews in Med. Chem., 16(7), 555-578.

[3] Zhang, L., Dou, X. W., Zhang, C., Logrieco, A. F., \& Yang, M. H. (2018). A review of current methods for analysis of Mycotoxins in herbal medicines. Toxins (Basel), 10(2), 65.

[4] McIntyre, E., Saliba, A. J., Wiener, K. K., \& Sarris, J. (2016). Herbal medicine use behaviour in Australian adults who experience anxiety: a descriptive study. BMC Complement. Altern. Med., 16, 60.

[5] Nadeem, M., \& Zeb, A. (2018). Impact of maturity on phenolic composition and antioxidant activity of medicinally important leaves of Ficus carica L. Physiol. Mol. Biol. Pla., 24(5), 881887.

[6] Hemmatzadeh, F., Fatemi, A., \& Amini, F. (2003). Therapeutic effects of fig tree latex on bovine Papillomatosis. J. Vet. Med. B. Infect. Dis. Vet. Public Health, 50(10), 473-476.

[7] Aref, H. L., Salah, K.B., Chaumont, J. P., Fekih, A., Aouni, M., \& Said, K. (2010). In vitro antimicrobial activity of four Ficus Carica Latex fractions against resistant human pathogens (antimicrobial activity of Ficus Carica Latex). Pak. J. Pharm. Sci., 23(1), 53-58.

[8] Raskovic, B., Lazic, J., \& Polovic, N. (2016). Characterisation of general proteolytic, milk clotting and antifungal activity of Ficus Carica Latex during fruit ripening. J. Sci. Food Agr., 96(2), 576-582.

[9] Nizamani, P., Afridi, H. I., Kazi, T. G., Talpur, F. N., \& Baig, J. A. (2019). Essential trace elemental levels (zinc, iron and copper) in the biological samples of smoker referent and pulmonary tuberculosis patients. Toxicol. Reports, 6, 1230-1239.

[10] Li, Y., Sun, L., Lu, C., Gong, Y., Li, M., \& Sun, S. (2018). Promising antifungal targets against Candida Albicans based on 1on homeostasis. Front. Cell. Infect. Microbiol., 8, 286.

[11] Aggarwal, K., Jain, V. K., \& Sangwan, S. (2003). Comparative study of Ketoconazole sersus selenium sulphide shampoo in pityriasis versicolor. IJDVL, 69(2), 86-87.
[12] Savi, G. D., Bortoluzzi, A. J., \& Scussel, V.M. (2013). Antifungal properties of zinccompounds against toxigenic Fungi and Mycotoxin. Int. J. Food Sci. Technol., 48, 18341840.

[13] Hana, R., Alzahrani, H. R., Kumakli, H., Ampiah, E., Mehari, T., Thornton, A. J., Babyak, C. M., \& Fakayode, S. O. (2017). Determination of macro, essential trace elements, toxic heavy metal concentrations, crude oil extracts and ash composition from Saudi Arabian fruits and vegetables having medicinal values. Arab. J. Chem., 10(7), 906-913.

[14] Eğil, E., Duman, C., Ünlü, Ö., Demirci, M., Altan Sallı, G., Özdal Zincir, Ö., \& Katiboğlu, A. B. (2020). Siyah Havuç, Vişne ve Nar Konsantrelerinin Streptococcus Mutans'in Biyofilm Oluşturma Özelliği Üzerine Etkisinin Değerlendirilmesi. Türkiye Klinikleri J. Dental Sci., doi: 10.5336/dentalsci.2020-77374.

[15] Kilınç, E., Buturak, B., \& Ateş Alkan, F. (2020). Level of trace elements in serum and toenail samples of patients with Onychocryptosis (ingrown toenail) and Onychomycosis. JTEMB., 61, 126509.

[16] Duzgun Ergun, D., Dursun, S., Ergun, S., \& Ozcelik, D. (2021). The Association Between Trace Elements and Osmolality in Plasma and Aqueous Humor Fluid in Diabetic Rabbits. BTER., doi. 10.1007/s12011-020-02538-5.

[17] Ahmed, N. M. Antifungal and Antibacterial activity of Fig Fruit Latexes from two Ficus species Plants. 3rd Scientific Conference College of Veterinary Medicine -University of Tikrit 2,3 May 2016.

[18] Karimiyan, A., Najafzadeh, H., Ghorbanpour, M., \& Hekmati-Moghaddam, S. H. (2015). Antifungal effect of magnesium oxide, zinc oxide, silicon oxide and copper oxide nanoparticles against Candida albicans. Zahedan J. Res. Med. Sci., 17(10), e2179.

[19] Kong, F., Wang, J., Han, R., Ji, S., Yue, J., Wang, Y., \& Ma, L. (2020). Antifungal activity of magnesium oxide nanoparticles: effect on the growth and key virulence factors of Candida albicans. Mycopathologia, 185, 485-494. 